\title{
Emerging Zika virus disease: a public health emergency of global concern
}

\author{
Sai V. Chitti ${ }^{1,2} \cdot$ Anil K. Prasad $^{1,2} \cdot$ Shailendra K. Saxena ${ }^{1,2}$
}

Received: 24 March 2016/Accepted: 13 April 2016/Published online: 5 May 2016

(C) Indian Virological Society 2016

\begin{abstract}
Infectious diseases remain a leading source of human morbidity and mortality. Recently, emerging infectious diseases are dominated by zoonoses, and eventually rising considerably. Their emergence is dependent on various factors especially, socioeconomic, environmental and ecological factors etc. Recently, the swift spread of Zika virus (ZIKV) through the Americas, simultaneously with the association of infection with microcephaly and Guillain-Barré syndrome, has strained this previously overlooked virus into the global attention. ZIKV is an emerging mosquito-borne Flavivirus, identified in rhesus monkey in 1947 in Uganda, and eventually in human in 1952. Considering the severity and recent spread over Americas, it has been declared as a public health emergency of international concern, and expected number of cases may be around three to four million. Therefore, it's important for all to assess the risk and be prepared in all possible ways before it makes a huge loss and spread globally. This news tries to discuss the possible reasons for its spread, risk assessment, and options to obliterate ZIKV.
\end{abstract}

Keywords Infectious diseases - Zika virus - Aedes . Receptors $\cdot$ Risk assessment and prevention

Shailendra K. Saxena

shailen@ccmb.res.in; shailen1@gmail.com

1 Centre for Advance Research (CFAR), King George's Medical University (KGMU), Lucknow 226003, India

2 CSIR-Centre for Cellular and Molecular Biology, Uppal Road, Hyderabad, TS 500007, India

\section{Introduction}

Emerging and reemerging infectious diseases recurrently come into notice from associations between various species. These pathogens may target humans with severe disabling diseases and remain a leading source of morbidity and mortality eventually. Their emergence is dependent on various factors especially, socioeconomic, environmental and ecological factors etc. The new emerging infectious diseases are dominated by zoonoses $(60.3 \%)$, and are rising considerably in due course of time [22]. Recently, the quick spread of Zika virus (ZIKV) through the Americas [2, 21], including the association of infection with microcephaly $[4,23,27]$ and Guillain-Barré syndrome, has fetched this previously overlooked virus into the global consideration by World Health Organization (WHO). It has recently come to worldwide concern owing to severity and recent spread to Western countries including pacific oceanic region and Brazil [9, 28, 30]. Expected number of ZIKV infection cases may be around three to four million. Earlier ZIKV outbreak has been reported in areas of Africa, Southeast Asia, and the Pacific Islands. The Pan American Health Organization (PAHO) epidemiological update reported that there was increase in congenital microcephaly and other central nervous system symptoms in the regions with active ZIKV infection [17] (http://www.paho. org/hq/index.php?option=com_content $\&$ view $=$ article\&id= 11599\&Itemid $=41691 \&$ lang=en).

ZIKV is a mosquito-borne Flavivirus belonging to the family Flaviviridae. It consists of single stranded positive sense RNA which is infectious. The genome is of 10,794 nucleotide long with 2 flanking noncoding regions ( $5^{\prime}$ and $3^{\prime} \mathrm{NCR}$ ) and a single long open reading frame encoding a polyprotein: $5^{\prime}$-CprM-E-NS1-NS2A-NS2BNS3-NS4A-NS4B-NS5-3', that is cleaved into capsid (C), precursor of membrane ( $\mathrm{prM}$ ), envelope (E) and seven non-structural proteins (NS) [6, 28]. 
Many members of the genus Flavivirus are the agents of important diseases of humans, livestock, and wildlife [13]. These viruses are often maintained in complex cycles involving vertebrates such as mammals or birds, pigs and blood-feeding vectors etc. ZIKV is believed to be transmitted to humans by infected mosquitoes (Fig. 1), of Aedes species (A. aegypti, A. albopictus, A. furcifer, A. taylori, A. luteocephalus and A. africanus) similarly as dengue and chikungunya viruses [3, 19]. Blood-feeding female Aedes mosquito injects the virus into human skin, followed by infection of permissive cells. Apart from mosquito-to-human transmission, ZIKV infections have been documented through intrauterine transmission resulting in congenital infection. Transmission from a viremic mother to her newborn was documented during 2013 outbreak in French Polynesia [25]. During Tahiti outbreak in 2013 it was reported that it can transmitted through sexual contact from an infected individuals $[1,14]$. Most recent report confirmed the vertical transmission of ZIKV from mother to fetus [26].

\section{Incidence and distribution}

According to WHO, ZIKV transmission has been documented in 59 countries and territories from 1 Jan 2007 to 16 Mar 2016 (Fig. 2), which reported autochthonous transmission (http:// www.who.int/emergencies/zika-virus/en/). ZIKV was first isolated in 1947 from a rhesus monkey in the Zika forest of Uganda and was first reported in humans in 1952 [8]. The first official epidemic was on the isolated island of Yap, Micronesia, in 2007. In 2013, ZIKV hit Tahiti, French Polynesia, with a huge outbreak. In 2014, virus arrived in Cook Island and North

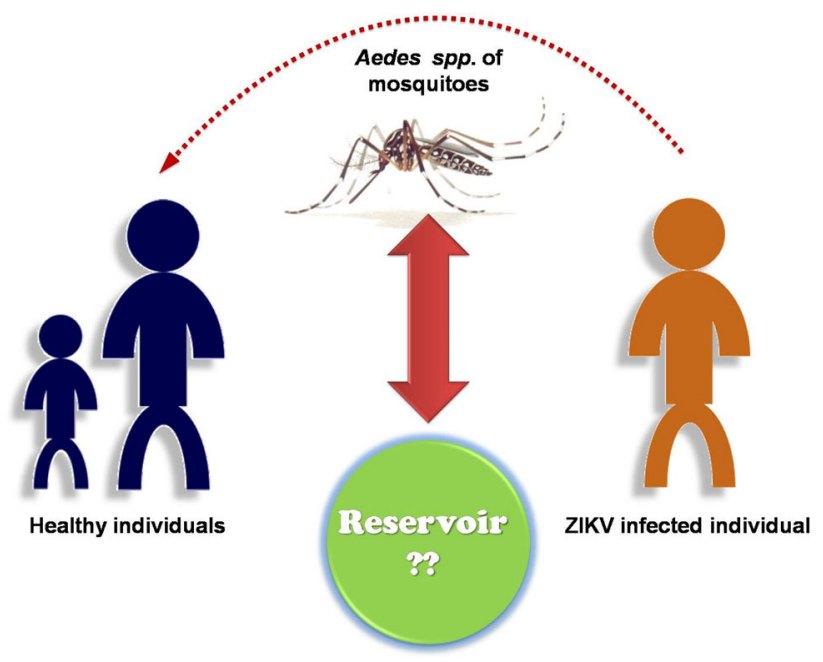

Fig. 1 Possible mode of ZIKV transmission: ZIKV spreads mainly through Aedes species of mosquitoes. Mosquito bites the infected patient and draws blood and contract the virus. When the same mosquito bites a healthy individual, the ZIKV enters and causes disease. The reservoir for ZIKV is still unknown
Caledonia. In 2015 and early 2016 it has reached Easter Island and South America [10] (http://www.who.int/emergencies/ zika-virus/situation-report/17-march-2016/en/).

\section{Entry receptors for ZIKV}

The first step of Flavivirus entry into a host cell is mediated by the viral envelope protein. Envelope protein interacts with cell surface receptors and attachment factors of the host, whose differential expression determines the cellular tropism, and thus of pathogenesis. Aedes mosquito deposits the virus in the epidermis and dermis of the bitten host during a blood meal. Skin fibroblasts, immature dendritic cells, and epidermal keratinocytes were found to be highly permissive to infection with ZIKV [18]. Heparan sulfate act as a nonspecific attachment factor of Flaviviruses, as it concentrates viral particles on the cell surface and facilitates their interaction with primary receptors [7]. The primary receptors includes C-type lectin receptors, such as the dendritic cell-specific intracellular adhesion molecule 3-grabbing nonintegrin (DCSIGN), the C-type lectin domain called family 5 member A (CLEC5A), TIM and TAM (Tyro3, Axl, and Mer) proteins. It was reported that DC-SIGN, AXL, Tyro3, and, to a lesser extent, TIM-1, permitted ZIKV entry, with a major role for the TAM receptor AXL. The role of these receptors in ZIKV entry was confirmed by the use of a neutralizing antibody and specific RNA silencing [18]. Virus replication occurs in the cellular cytoplasm [29].

\section{Clinical signs}

Clinical pictures range from asymptomatic cases to an influenza-like syndrome associated to mild fever (37.8-38.5 $\left.{ }^{\circ} \mathrm{C}\right)$, non-purulent conjunctivitis, headache, arthralgia, notably of small joints of hands and feet, myalgia, asthenia, maculo-papular rash and less frequently, retro-orbital pain, anorexia, vomiting, diarrhea and abdominal pain. These symptoms normally last for 2-7 days [5, 11, 20]. Incubation period for ZIKV is still not known.

Biological confirmation of ZIKV infections is based mostly on detection of virus RNA in serum by using reverse transcription $\mathrm{PCR}$, virus isolation or the detection of ZIKV specific IgM or IgG antibodies through serological tests [15]. ZIKV RNA was also detected in saliva and urine [16, 24]. There is neither vaccine to prevent nor specific anti-viral treatment available for ZIKV infection. Treatment is directed primarily at relieving symptoms using anti-pyretics that can reduce the fever and analgesics which relieves from joint and muscle pains. Additional treatment includes taking plenty of water, which can reduce the viral load in the body. 
Fig. 2 Countries and territories with active transmission of Zika virus-2016 as per the WHO

[41]

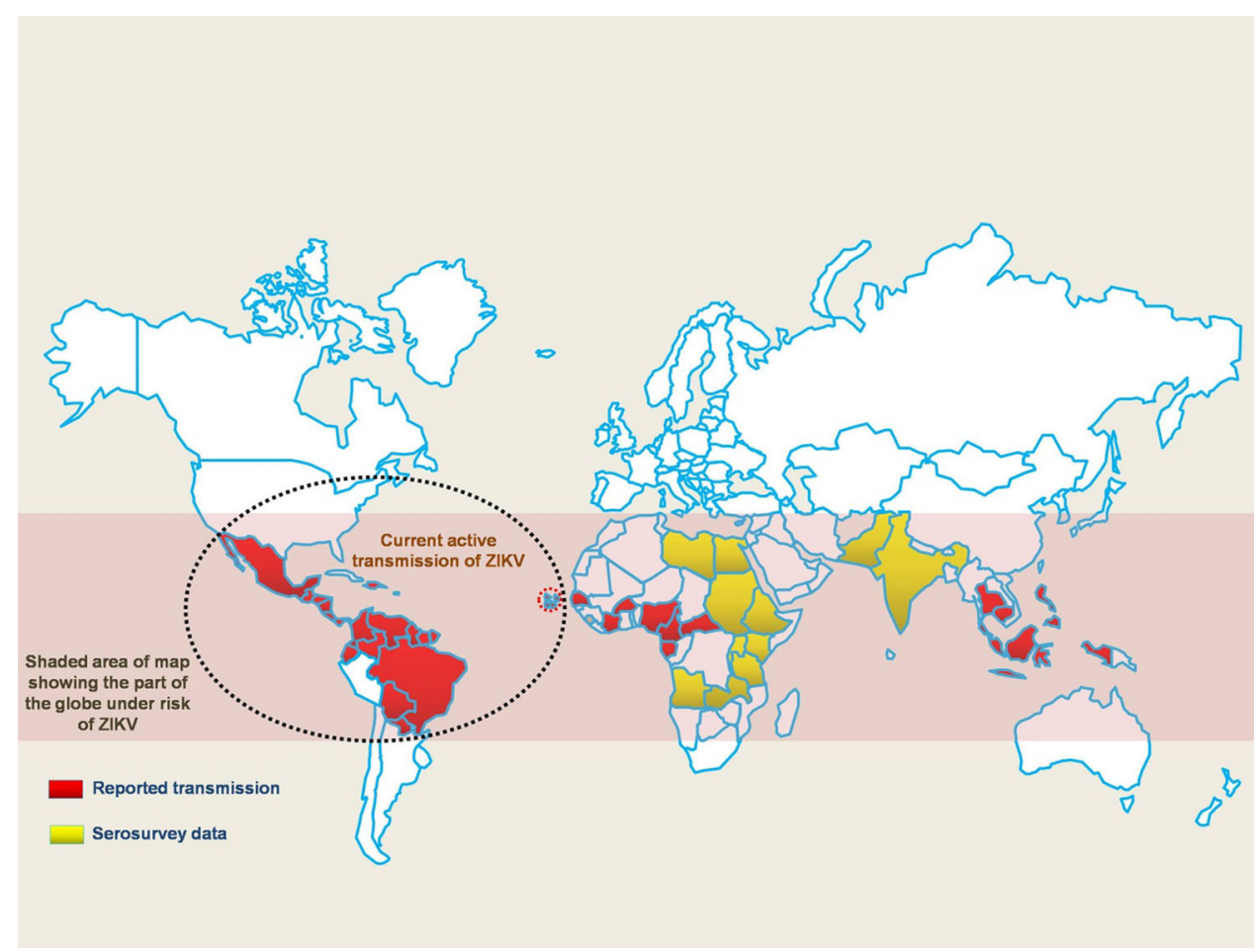

\section{Possible factors for the spread of ZIKV}

Environmental and other factors might be the reason for the spread of the arboviral diseases, because the several mosquito born diseases are confined to tropical regions. However, recent emergence of ZIKV and other viral diseases into the regions that have never experienced them clearly indicates the environmental role in spread of the viral disease. Environmental changes include global warming that causes the rise in temperature and helping to expand the range of places that are habitable to mosquitoes. The second reason includes trade and travel of humans.

\section{Risk assessment for ZIKV}

One of the prime responsibilities of any government is to look after the health and safety of its citizens. There are three key elements of health security: prevention wherever possible, early identification, and timely effective response. Although many countries manage infectious disease threats better than in the past, these enhancements have regularly been small in scale and limited in scope. It's important for every country to assess the risk of the particular disease before it makes a huge loss and spread globally. In the past 20 years arthropod-borne viral diseases are unexpectedly moving towards Western hemisphere from their putative origin from Asia and Africa. This clearly indicates that international concern is required about the emerging infectious disease. ZIKV is most likely maintained in a sylvatic cycle with cyclic epizooty connecting non-human primates and mosquitoes. The serological surveys indicated a silent circulation and antibodies have been detected in various animals including large mammals such as orangutans, zebra, elephants, water buffalo and rodents in West Africa and South-east Asia [12]. Moreover, the accelerated pace of globalization amplifies the risks: an outbreak anywhere is a threat everywhere. So, risk assessment and preventive steps need to be taken up immediately by governments and international bodies to counteract the ZIKV spread. Recently WHO has launched a global strategic response framework and joint operations plan to guide the international response to the spread of ZIKV infection and the neonatal malformations and neurological conditions associated with it (http://www.who.int/mediacentre/factsheets/zika/en/).

\section{Immediate steps to be taken}

The worldwide funds to counter disease emergence are poorly allocated. Reinforcing the health-care systems and immediate response from international bodies such as WHO and CDC etc., will be the best defense against outbreaks of any emerging infectious diseases which are potential international concern. In case of many viral infections, the outbreak had occurred in poor countries where there were no proper healthcare systems. However, building better health-care systems will take long time and requires human source and finances. Therefore, wealthy countries should support the poor countries 
for better development of health-care systems, since the spread of disease chances are there to every corner globally.

There is an urgent need to get serious about tracking ZIKV i.e., there should be proper surveillance. Mosquito control programs should be implemented immediately. Pregnant women should avoid traveling to the place where ZIKV is circulating. Public awareness programs about the ZIKV disease symptoms and precautions need to be speeded up. Blood safety authorities should consider the rescheduling of donors with a related travel history to the areas with active ZIKV transmission. Along with above mentioned points, it is important to pace up the study for specific antiviral search against ZIKV. For these doctors, scientists having expertise in infectious diseases, and other areas of biology should work collaboratively to conduct the preclinical studies and every other passageway needs to be examined to fight viral diseases.

Acknowledgments Authors are grateful to the Vice Chancellor, King George's Medical University (KGMU), Lucknow and Director, Centre for Cellular and Molecular Biology and Council of Scientific and Industrial Research (CSIR-CCMB), India for the encouragement and support for this work. SK Saxena is also supported by US National Institute of Health Grants: R37DA025576 and R01MH085259.

\section{References}

1. Aubry M, Finke J, Teissier A, Roche C, Broult J, Paulous S, Desprès P, Cao-Lormeau VM, Musso D. Seroprevalence of arboviruses among blood donors in French Polynesia, 2011-2013. Int J Infect Dis. 2015;41:11-2.

2. Ayres CF. Identification of Zika virus vectors and implications for control. Lancet Infect Dis. 2016;. doi:10.1016/S14733099(16)00073-6.

3. Besnard M, Lastere S, Teissier A, Cao-Lormeau V, Musso D. Evidence of perinatal transmission of Zika virus, French Polynesia, December 2013 and February 2014. Euro Surveill. 2014;19(13):20751.

4. Butler D. Zika virus: Brazil's surge in small-headed babies questioned by report. Nature. 2016;530:13-4.

5. Carneiro LA, Travassos LH. Autophagy and viral diseases transmitted by Aedes aegypti and Aedes albopictus. Microbes Infect. 2016;. doi:10.1016/j.micinf.2015.12.006.

6. Chen LH, Hamer DH. Zika Virus: rapid Spread in the Western Hemisphere. Ann Intern Med. 2016;. doi:10.7326/M16-0150.

7. Chen Y, Maguire T, Hileman RE, Fromm JR, Esko JD, Linhardt RJ, Marks RM. Dengue virus infectivity depends on envelope protein binding to target cell heparan sulfate. Nat Med. 1997;3:866-71.

8. Dick GW, Kitchen SF, Haddow AJ. Zika virus. I. Isolations and serological specificity. Trans R Soc Trop Med Hyg. 1952;46:509-20.

9. Duffy MR, Chen TH, Hancock WT, Powers AM, Kool JL, Lanciotti RS, Pretrick M, Marfel M, Holzbauer S, Dubray C, Guillaumot L, Griggs A, Bel M, Lambert AJ, Laven J, Kosoy O, Panella A, Biggerstaff BJ, Fischer M, Hayes EB. Zika virus outbreak on Yap Island, Federated States of Micronesia. N Engl J Med. 2009;360:2536-43.

10. European Centre for Disease Prevention and Control. Rapid risk assessment: Zika virus infection outbreak, French Polynesia-14 February 2014. Stockholm: ECDC; 2014.
11. European Centre for Disease Prevention and Control. Rapid risk assessment: Zika virus epidemic in the Americas: potential association with microcephaly and Guillain-Barré syndrome-10 December 2015. Stockholm: ECDC; 2015.

12. European Centre for Disease Prevention and Control. Zika virus epidemic in the Americas: potential association with microcephaly and Guillain-Barré syndrome (first update) 21 January 2016. Stockholm: ECDC; 2016.

13. Fauci AS, Morens DM. Zika virus in the Americas-yet another Arbovirus threat. N Engl J Med. 2016;374:601-4.

14. Foy BD, Kobylinski KC, Chilson Foy JL, Blitvich BJ, Travassos da Rosa A, Haddow AD, Lanciotti RS, Tesh RB. Probable nonvector-borne transmission of Zika virus, Colorado, USA. Emerg Infect Dis. 2011;17:880-2.

15. Gatherer D, Kohl A: Zika virus: a previously slow pandemic spreads rapidly through the Americas. J Gen Virol. 2015.

16. Gourinat AC, O'Connor O, Calvez E, Goarant C, Dupont-Rouzeyrol M. Detection of Zika virus in urine. Emerg Infect Dis. 2015;21:84-6.

17. Haddow AD, Schuh AJ, Yasuda CY, Kasper MR, Heang V, Huy R, Guzman H, Tesh RB, Weaver SC. Genetic characterization of Zika virus strains: geographic expansion of the Asian lineage. PLoS Negl Trop Dis. 2012;. doi:10.1371/journal.pntd.0001477.

18. Hamel R, Dejarnac O, Wichit S, Ekchariyawat P, Neyret A, Luplertlop N, Perera-Lecoin M, Surasombatpattana P, Talignani L, Thomas F, Cao-Lormeau VM, Choumet V, Briant L, Desprès $\mathrm{P}$, Amara A, Yssel H, Missé D. Biology of Zika virus infection in human skin cells. J Virol. 2015;89:8880-96.

19. Hayes EB. Zika virus outside Africa. Emerg Infect Dis. 2009;15:1347-50.

20. Heang V, Yasuda CY, Sovann L, Haddow AD, Travassos da Rosa AP, Tesh RB, Kasper MR. Zika virus infection, Cambodia, 2010. Emerg Infect Dis. 2012;18:349-51.

21. Hennessey M, Fischer M, Staples JE. Zika virus spreads to new areas-region of the Americas, May 2015-January 2016. MMWR Morb Mortal Wkly Rep. 2016;65:55-8.

22. Jones KE, Patel NG, Levy MA, Storeygard A, Balk D, Gittleman JL, Daszak P. Global trends in emerging infectious diseases. Nature. 2008;451:990-3.

23. Mlakar J, Korva M, Tul N, Popović M, Poljšak-Prijatelj M, Mraz J, Kolenc M, Resman Rus K, Vesnaver Vipotnik T, Fabjan Vodušek V, Vizjak A, Pižem J, Petrovec M, Avšič Županc T. Zika virus associated with microcephaly. $N$ Engl J Med. 2016;374:951-8.

24. Musso D, Roche C, Nhan TX, Robin E, Teissier A, Cao-Lormeau VM. Detection of Zika virus in saliva. J Clin Virol. 2015;68:53-5.

25. Musso D, Roche C, Robin E, Nhan T, Teissier A, Cao-Lormeau VM. Potential sexual transmission of Zika virus. Emerg Infect Dis. 2015;21:359-61.

26. Oliveira Melo AS, Malinger G, Ximenes R, Szejnfeld PO, Alves Sampaio S, Bispo de Filippis AM. Zika virus intrauterine infection causes fetal brain abnormality and microcephaly: tip of the iceberg? Ultrasound Obstet Gynecol. 2016;47:6-7.

27. Rubin EJ, Greene MF, Baden LR. Zika virus and microcephaly. N Engl J Med. 2016;374:984-5.

28. Tappe D, Pérez-Girón JV, Zammarchi L, Rissland J, Ferreira DF, Jaenisch T,Gómez-Medina S, Günther S, Bartoloni A, MuñozFontela C, Schmidt-Chanasit J: Cytokine kinetics of Zika virusinfected patients from acute to reconvalescent phase. Med Microbiol Immunol. 2015.

29. Tiwari S, Chitti SVP, Mathur A, Saxena SK. Japanese encephalitis virus: an emerging pathogen. Am J Virol. 2012;1:1-8.

30. Zanluca C, de Melo VC, Mosimann AL, Dos Santos GI, Dos Santos CN, Luz K. First report of autochthonous transmission of Zika virus in Brazil. Mem Inst Oswaldo Cruz. 2015;110:569-72. 